\title{
Factors generating reluctance in the oral participation in an English class
}

\section{Factores que generan reticencia en la participación oral en una clase de inglés}

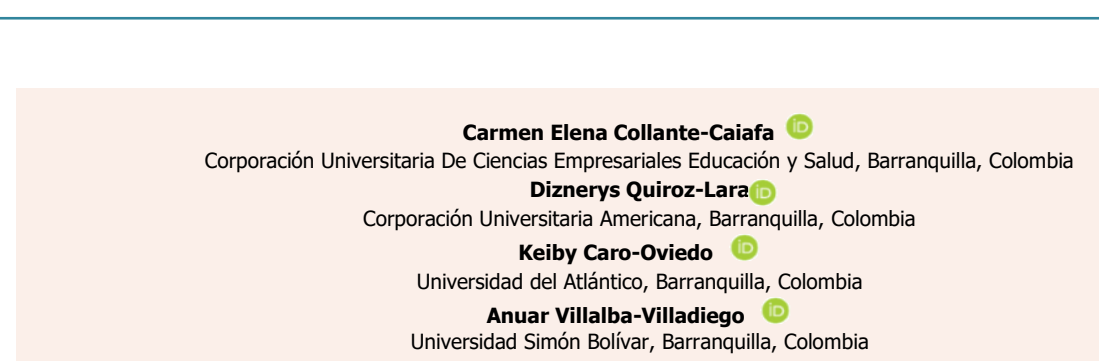

Abstract

Objective: present the main factors causing reluctance of a target group to partake in English oral activities. Method: the techniques used for this inquiry were the classroom observation and the interview; in addition, a questionnaire was applied to the students, from which a focus group was drawn. Results: the results indicated that these students were aware of their limitations regarding the lack of vocabulary and a solid pronunciation. Discussion y Conclusion: this study confirmed that anxiety, low motivation for communication, low self-confidence in learning a foreign language, the teacher's method to monitor oral activities, the fear of making mistakes and the fact of being ridiculed by peers are some shared factors affecting these students' oral participation.

Keywords: language learning, oral expression, interactive communication, selfesteem, motivation

\section{Resumen}

Objetivo: presentar los principales factores que causan reticencia de un grupo de estudiantes a participar en actividades orales en inglés. Método: las técnicas utilizadas para esta investigación fueron la observación de clase y la entrevista; además se aplicó un cuestionario a los estudiantes, de los cuales se extrajo un grupo focal. Resultados: los resultados indicaron que estos estudiantes eran conscientes de sus limitaciones en cuanto a la falta de vocabulario y de una pronunciación sólida. Discusión y Conclusiones: este estudio confirmó que la ansiedad, la escasa motivación para la comunicación, la poca confianza en sí mismos a la hora de aprender un idioma extranjero, el método del profesor para supervisar las actividades orales, el miedo a cometer errores y el hecho de ser ridiculizados por los compañeros son algunos de los factores comunes que afectaban la participación oral de estos estudiantes.

Palabras clave: aprendizaje de idiomas, expresión oral, comunicación interactiva, autoestima, motivación.
Open Access:

E-ISSN: $2665-2420$

ISSN: $0124-2121$

Research article Copyright @ 2020 By Educación y Humanismo

Editor: Dhayana Fernández Matos Universidad Simón Bolívar

Received: 26-07-2020 Accepted: $02-09-2020$ Online from: $23-10-2020$ 


\section{Introduction}

The current Colombian educational system is mostly aimed to form integral and abiding citizens by providing the necessary skills and abilities that allow them to participate actively in a globalized world. Among them, the command of English as a foreign language is viewed as a requirement to have better labor opportunities and to be competent in different fields; therefore, communication is considered the ultimate goal within the language teaching and learning process.

However, it is commonplace that high school students are reluctant to use the foreign language before their classmates and also in other contexts despite the increasing use of English in fashionable environments such as music, movies, TV and technological contexts. Motivating learners to use English is very important to foster their communicative competence, but some of them prefer to practice other types of tasks such as grammar exercises, writing, reading rather than using the language to convey messages.

Speaking is one of the most desirable skills to be managed for people who want to learn a language for interaction purposes, exploration of some other cultures and exchange of knowledge. This skill is related to interactional competence that requires people to be able to communicate socially through the uses of language rules (Hughes \& Szczepek Reed, 2017). In fact, language learning should be focused on the way, in which learners can use English to meet their necessity of communication in contexts where it is required.

Undoubtedly, mastering a foreign language in today's globalized and digitalized world is required to communicate with others effectively and expand the world knowledge. It is well known that first-hand information is available in English and this language is the preferred means of communication. Due to this, the educational system should provide students with upto-date tools, skills and knowledge to make them competent and competitive to be part of the world citizenship.

Based on the aforementioned, the Colombian government on behalf of the Ministry of Education has given priority to English as a foreign language and both have made substantial efforts in order that Colombian students can develop their communicative competence in this language. Since the year 2004, several national programs have been promoted and implemented to strengthen the learning of English at schools and universities. These include the Programa Nacional de Bilingüismo (PNB) 2004-2019 (Ministerio de Educación Nacional, s.f.), the Programa de Fortalecimiento en Lenguas Extranjeras (PFDCLE) 2010-2014, the Programa Colombia Bilingüe 2014-2018 (Ministerio de Educación Nacional, 2014), and the Programa Nacional de Inglés 'Very well' 2015-2025 (Ministerio de Educación Nacional, s.f). All of these programs seek to make students use English for communication, academic strengthening and employment opportunities. This policy reaffirms the necessity of the development of communicative competence in a foreign language. 
It is worth stressing that most of the bilingual policies and strategies along with the current communicative competence model implemented in Colombia are based on the guidelines of the Common European Framework of References for Languages. The Colombia Ministry of Education has adopted them thoroughly without contextualizing the educational situation in this country (Gómez, 2017), although the Council of Europe (2018) declared new descriptors for learning, teaching and assessment recently.

Consequently, the identification of the causes generating reluctance when speaking might help teachers to search for new strategies that can boost the participation of their students in oral activities and the development of the communicative competence in English. Nevertheless, the reality in some schools, especially public schools in small towns, does not reflect the desire for communicating in the foreign language. Speaking seems to be a very difficult skill to develop because students are reluctant to use the language freely for oral activities. They prefer some other silks such as writing, reading or participating in dialogues previously memorized to have a passing mark instead of using the language to get their ideas across.

The main goal of language academic programs should focus on communication; it means, presenting and practicing the structures of the language for communicating in real contexts. However, the activities implemented in class do not favor communication in class; students do not use the language meaningfully. In fact, they use the foreign language mostly for repetition and memorization.

Regarding this situation, it is pivotal to study the factors that inhibit the use of the foreign language and the participation in oral activities. There are internal and external aspects that need to be analyzed to overcome those barriers which do not allow students to develop their communicative competence effectively.

Language anxiety, nervousness and low confidence are some of the internal factors that could be the causes of this fear of speaking. Therefore, this research attempts to shed light on a couple of factors that influence the reluctance of students to participate in oral activities. This has been carried out through the analysis of students' behavior and attitudes during speaking practice in class to determine the real origin of this low participation, and to reflect on the specific strategies to cope with this problem. This can allow students to use the target language for communication purposes and active class participation.

Prior to delving into the overall description of this research study, it is noteworthy to define the key concepts related to the oral communication to have a better insight into the root causing the students' reluctance to speak in class. They are speaking, communicative language teaching, interaction, affective factors affecting communicative competence, anxiety, self-esteem, inhibition, risk-taking, motivation, sociocultural approach, and teacher's meditation and scaffolding.

Speaking. It is considered a productive skill and many people think it is very simple to teach and learn. This is supported by Heini-Marja (2019) when affirming that "speaking is an important skill in language learning, but it is not an easy skill to learn or teach" (p.95). However, speaking is one of the most complex and dynamic skills because it encompasses the use of 
simultaneous processes such "grammar, sound, vocabulary and even cultural knowledge of the language" (Koran, 2015, p. 403). This skill should be developed in class as one of the goals; it gives learners the ability to speak coherently and clearly on different issues. In this regard, Nunan (2018) points out that it is necessary to draw a distinction between reproductive speaking and creative speaking. The first refers to the repetition of language forms provided by a model (the teacher or a recording/ audiolingual segment). The second concerns to the use of one's own meanings as replies to the other's meanings (Nunan, 2015). As the British Council (n.d) asserts, speaking can be improved by noticing the language we use in different situations and by practicing.

Communicative Language Teaching. The communicative language (CLT) is closely related to the development of communicative competence. The concept of communicative competence was introduced by Hymes (1966) and later redefined by many authors (Campbell \& Wales, 1970; Canale \& Swain, 1980; Savignon, 1972). Hymes (1972) argued that speakers of a language need to have more than grammatical competence to be able to communicate effectively. Even if the approach is CLT, Heini-Marja (2019) states that "oral language is rarely used in the classroom, or even if there are interaction activities and simulations" (p.95). In line with it, Cotter (2007) remarks that oral skills compel students to use the language productively, to interact significantly and to perceive the foreign language as a tool for social interaction. Richards (2006) complements that the focus should be on language functions. Considering this, the goal of language teaching is the use of the target language for communicating significantly instead of uttering accurate sentences.

Interaction. The increasing interest to be competent, express ideas to others and understand authentic messages in real conversations has drawn the attention to interaction in class. Linking with that, Rohmah (2017) expresses that all activities in class should include "both verbal interaction and non-verbal interaction. Verbal interaction covers written interaction and oral interaction" (p. 193). Viewed in this way, classroom interaction is considered a productive teaching technique, where students can build up confidence in each other and put into practice all what has been learned in real conversation contexts (McDonough \& Mackey, 2013). In doing so, students can receive comprehensible input, produce new messages and give feedback to others. Definitively, speaking skill is concerned with interactional competence since it requires people to be able to communicate socially through the uses of language rules (Hughes \& Szczepek Reed, 2017).

Affective factors influencing students' reluctance to speak. Most of the scholars (Galajda, 2017; Nie, 2018; Hoang Tuan \& Ngoc Mai, 2015) have agreed and identified nervousness, anxiety, lack of vocabulary and self-confidence as some of the aspects that might influence the reluctance to use the language and to interact in class. It is commonplace to find students who show great expectations and high motivation towards the foreign language, but there are some others who are reticent to speak or interact with other peers or the teacher. This is mostly because students have fear, feel embarrassed or lack the command to speak the language (Hamouda, 2013). This situation causes low participation and reluctance to take part in oral activities. To comprehend some of the factors influencing the reluctance to speak and get involved in oral activities, it is essential to explore the reasons or affective factors that actually bring about this reluctance. By doing this, some strategies can also emerge to overcome 
this situation in class.

Anxiety. It is similar to inhibition and is one of the psychological factors influencing oral communication negatively. It is manifested in tension or worriedness as a response of nervous system. Elaldi (2016) claims that "foreign language anxiety can occur if students are exposed to several negative experiences in a foreign language context" (p.220) such as fear of making mistakes, lack of confidence and shyness. This can be caused not only by teachers, but also by classmates. Anxiety also affects students' speaking performance and sometimes the whole learning process (Ariyanti, 2016). Developing speaking skills and interacting with others using a foreign language is a complex and an overwhelming task. In fact, students can experience anxiety attacks when performing a speaking activity in class.

Self-esteem. Robertson (2018) explains that human beings have five primary needs derived from Maslow's Hierarchy of Needs theory. These are physiological, safety/security, social, self-esteem and self-actualization. Among them, self-esteem is the need where humans obtain their recognitions and know their self-worth. Robertson (2018) explains what Maslow defines as self-esteem. He affirms it is a personal judgment of worthiness that is expressed in attitudes that the individual holds towards himself, and indicates the extent to which the individual believes in himself to be capable, significant and worthy. This author is convinced that self- esteem is a very essential quality in students because when they believe in their own abilities and capabilities, learning can occur.

Inhibition. Humaera (2015) discloses that there are two main elements causing inhibition: cognitive factors (grammar, vocabulary, pronunciation) and affective factors (lack of motivation, shyness, self-confidence, self-esteem, language ego, classroom interaction, fear of language evaluation). Inhibition might be regarded as a problem mainly in adolescents, who are in a transition age and are more conscious than younger learners. It is quite common to find inhibition in foreign language classrooms. According to Lai-Mei and Seyedeh (2017), "inhibition is the first problem that students encounter in class. When they want to say something [...] they are worried about making mistakes and fearful of criticism. They are ashamed of the other students' attention towards themselves" (p.36). In fact, a great lesson could fail if the students' needs and personalities are undervalued in the process of planning a class.

Risk-taking. Risk-taking is an ability of being eager to try out new information intelligently regardless of embarrassment in linguistics. Risk-taking has been identified as a personality trait related to spoken English learning. "Risk taking may entail impulsiveness and keep a correlation with extroversion, introversion, and self-confidence among others. In terms of skills, most of the literature regarding risk taking has focused on speaking rather on the other macro skills" (Marín, 2013, p. 422). Duell and Steinberg (2018) hold that adolescents are more likely to take risks than children or adults, but it is rare to see adolescents take the risk of participating in class during oral activities. This is due mostly to the fear of being ridiculed or embarrassed by some factors, both cognitive and affective, that restrain them to take up some new challenges.

Motivation. It could be considered one of the most significant factors that affect the learning process; in fact, higher motivation might lead to a successful learning. Karahan, (2007) considers that motivation is the emotion that a person could have towards learning a foreign 
language, and it is determined by his/her predispositions and characteristics of personality. OgaBaldwin and Fryer (2018) allege that motivation can influence and be influenced by the dynamics of language learning. Considering the speaking skill in a foreign language, the teacher's belief can positively or negatively influence the orientation of their students' motivation. Due to this, low motivation can lead to serious difficulties in speaking on the part of students regardless of having acceptable linguistic skills.

On the other hand, to pursue a particular goal, people depend on the incentives of the situation and personal preferences, as well as the interactions that are seen as motivation (Heckhausen \& Heckhausen, 2018). Based on their age, learners have different rates of motivation; nonetheless, there are a plethora of techniques which students can apply allowing for their own learning needs and the motivational orientation from their teacher.

Sociocultural approach to language learning. The teacher's role is relevant to cope with the diverse affective factors that cause reluctance when using the target language for communicating with others and fostering students' interaction and active participation in oral activities. In this sense, the sociocultural theory grounds language teaching and learning by establishing the need for social interaction and meaning construction; hence, it is necessary to review some ideas of this perspective making deeper emphasis on teachers as mediators and the process of scaffolding to improve the language learning and the development of communicative skills.

The sociocultural theory's conceptualizations are drawn basically on the work of Vygotsky (1986), and also on some other theoreticians such as Lantolf and Thorne (2007), and Swain et al., 2015). Teachers and students have essential roles to play in the classroom; teachers can mediate through their talks or conversations in the classroom. The teacher, then, is the mediator who facilitates the appropriateness or the internalization of concepts in apprenticeship zones created by the teacher and the student (Hameed Panhwar et al., 2016).

Teacher's mediation and scaffolding. Based on the sociocultural theory and a large number of empirical studies carried out on the effectiveness of scaffolding in learning a second or foreign language, it has been found that expert peer scaffolding is the most effective procedure for the development of listening skill (Ahmadi Safa \& Rozati, 2017). This ability is closely related to speaking and scaffolding can be expected to be an effective strategy in its development. Under this view, teachers mediate through their talks or conversations in the classroom. Their role is pivotal since students' achievements might take place during the interaction, when teachers provide explanations, ask questions, give and receive feedback, give directions, accept feelings, etc. Currently, the role of teachers is to invite students to take more significant participation within the class activities rather than teacher's.

\section{Method}

Ethnography was selected to carry out this qualitative study since the objective is to understand the behavior of a particular social or cultural group. As Richards (2003) puts it, ethnography refers to the social world and has to do with the description of a group. 
Ethnography is a method of social science inquiry in which the researcher embeds himself/herself in the ongoing interactions of a particular social setting or set of relations to understand and explain members' lived experience. In line with it, Colin and Shamus (2018) state that "ethnographers follow, observe, interview, and participate in the routines of the people they study. This allows them to capture meanings, behaviors, intentions, and interactions that are often glossed by methods that are more distant (e.g., surveys) or contrived (e.g., experiments)" (p.xi).The most pertinent philosophical perspective or research approach is hermeneutic that involves the process of communication, interpretation and understanding as key elements. Hermeneutics in research is appropriate to the interpretive paradigm that collects information through the description of personal experiences, the conversational interview and observation, which is permeated by its reflective nature and possibility to analyze its meanings (Kivunja \& Kuyini, 2017).

\section{Participants and context}

The participants of this research process are a group of $8^{\text {th }}$ graders at San Jose de Luruaco School and one English teacher. This group is made up of 46 students, 30 girls and 16 boys whose ages range from 12 to 15 . They started learning English in $6^{\text {th }}$ grade. Their proficiency level according to the Common European Framework is that of A1 or lower. This research study took place at the Institución Educativa San José de Luruaco: a public institution that offers preschool, primary and high school studies. The school has 1.300 students approximately. It is located in Luruaco - Atlántico; a small town far away from the capital Barranquilla and near Cartagena. Most of the students come from low-income families. The town economy is based on farming and informal trade. A reduced number of parents are professionals or belong to a higher social stratum.

The Institution is facing the challenge of implementing a tourism project in association with Colegios Amigos del Turismo, the Ministry of Commerce, Industry and Tourism, and the support of the Universidad Externado de Colombia. Prior to this, it is essential to give a privileged position to the English subject in the curriculum. Firstly, the number of teaching hours per week needs to be increased; secondly, the investment on technological resources has to be improved in order to change the way of teaching this subject and also encourage students to learn the foreign language and provide effective English language training to all teachers at the institution.

\section{Tools}

During this process, different data collection tools were applied. There were four classroom observations recorded, one focus group interview to eight students and two questionnaires: one applied to the target group and another to the English teacher. These are typical instruments for data collection in qualitative studies, and they were appropriate for collecting quality data in the present research.

The classroom observations were made to pinpoint the affective factors influencing the students' reluctance to speak English in class. They also served to analyze the strategies implemented by the teacher to encourage class participation as well as the target group's 
attitudes towards their peers during the oral activities. The questionnaires, the interviews, and the focus groups contributed to confirm or enhance the information collected.

\section{Procedure}

The classroom observations were aimed at identifying three different aspects such as the students' attitudes towards oral activities, the interaction with partners and teacher and the motivation for participation. An interview to a teacher was also conducted at the beginning of the research process in order to gain insights into the development of communication skills in class and the effectiveness of the activities proposed to improve class participation. At the end of the process, it was necessary to design and apply another interview to a focus group composed of eight students. These students were chiefly selected considering the high or low participation displayed during the classroom observations. It was a semi-structured interview, in which the students could express freely their insights about their own participation in class, their classmates' behavior towards oral activities and the obstacles that inhibited them to speak English and partake in oral activities.

\section{Results}

After having applied the instruments, the results obtained are presented as follows:

\section{Description of the classroom observations}

Four classroom observations were recorded to have a broader picture of the students' behavior during the class:

The first class observation was conducted at random to find more reliable evidence of what the teacher and the students actually performed during the oral activities. The teacher read a passage from the course textbook aloud and carried out a warm-up activity by asking some questions on the selected topic. In this segment, it was evident that the students were reluctant to get involved in them. At first, they had problems with the exercise or they were not familiarized with the vocabulary; however, when the questions were translated into Spanish, they were willing to participate actively by using the mother tongue despite using the vocabulary provided by the text. Then, the teacher asked for a volunteer to read the text aloud. There were no volunteers; therefore, the teacher had to call on a student. It took this student by surprise and made him hesitate to read it. Due to this, another student took over and read. It was clearly noticed reading aloud was difficult for them, in particular, this kind of reading passage that entailed some scientific names. The vocabulary was not previously taught and this could have been the cause of the hesitation within the target group. In the last segment, the teacher gave the respective instructions in L2 to start working on the planned activities. However, the students did not grasp the instruction thoroughly and stayed put for a while. The teacher realized they could not grasp the instructions and translated them into Spanish. Most of the students were inhibited to talk about the topic due to the lack of comprehension in $L 2$. In the next part of the class, the students requested new explanations, but finally the teacher decided to give the instructions and clarifications in Spanish. This way, they were more 
comfortable to ask the teacher and work on the activities. In fact, the use of English in the class was reduced to merely search unknown words in the dictionary and translate the text into Spanish to gain reading comprehension.

The second classroom observation was planned along with the teacher and revolved around the future plans and arrangements; the grammar structure was the form of going to and vocabulary related to these verbs. At the beginning of the class, the teacher did a warming up activity in order that the target group could remember the structure of going to, which was taught in the previous lesson. They did not answer immediately and tried to review the notes to respond. The whole class was receptive and willing to get involved during the oral activities.

During the third classroom observation, the teacher continued developing the topic displayed in the preceding lesson and asked some students to partake in the exercise. However, the group was reluctant to do it voluntarily. For this reason, the teacher always had to encourage them to get involved with the activities. The class was divided into two moments; the first moment was devoted to reviewing the structure of going to by analyzing example sentences containing errors written on the board. The objective was to identify the errors and support their choice. Most of the students became inhibited to do it even though they seemed to master the topic. The other moment of the class was dedicated to putting into practice the grammatical item learned through an oral activity. The students were supposed to form a question and asked it using the grammatical pattern. The teacher stressed that they only had to think about a question, not to write it, but all of them preferred writing the sentence or reading it from their notebooks to feel at ease. Despite all this, most of the group could manage the grammar structure. In the end, the teacher had the students write a dialogue using some of the structures learned. The teacher monitored the classwork and these dialogs were acted out with a certain degree of difficulty. Once again, it was really complicated for the teacher to lower the affective filter and make them lose their fear to perform before their peers.

The last class was planned together with the teacher to observe the participation of the target group performing oral activities. The topic selected was aimed at reinforcing the daily routines since the students were acquainted with them because both the simple present tense and the frequency adverbs had already been explained previously. The aim of this topic was to form questions and talk about the daily routines. In order to achieve that, the teacher prepared a PPT presentation to make the class appealing and interesting. At the beginning of the class, the teacher activated the previous knowledge by presenting the vocabulary and by making them repeat and practice the pronunciation. Shortly after, she asked some of them about the activities they usually carried out on a daily basis. The teacher projected a dialogue based on this topic as a model for the students to follow. After that, they were asked to interact with their peers using similar patterns and the teacher monitored them. This activity turned out to be successful and the group seemed highly motivated.

Once finished, the teacher had some pairs perform the dialogues in front of the class. Unfortunately, this activity failed because they felt anxious, uncomfortable as well as unprepared to do it. It was evident that the communication activity did not meet the objective because the students did not get their ideas across. They simply repeated the verb forms. In this part, the student answered without having listened to the question. Nevertheless, they 
resorted to Spanish to aid their partners to repeat and use the grammar forms accurately. It is worth highlighting the students were worried about the use of grammar instead of communicating their ideas. As a matter of fact, all the students showed anxiety when presenting the dialogues. Some were moving a lot while others repeated the words more than twice and others laughed nervously.

\section{Description of focus group interview}

After the classroom observations, it was necessary to know the students' impressions about their participation in English classes considering the situations observed for the last two classes. Eight students were selected based on their level of participation. Most of them evidenced symptoms of anxiety during the performance of the oral activities in class. The interview was semi-structured, which means that there was a list of questions previously organized. Most of the questions were focused on the interviewee's replies and conducted like a friendly and nonthreatening conversation. The students could respond to the questions as they wanted to do it.

The students were willing to collaborate with the interview even though they seemed to be a little stressed, but then they felt relaxed when they were explained that they would not be evaluated and the questions and answers would be given all in Spanish.

The attendees were inquired about how interesting they considered studying English at school. Two of them said that the main objective for studying English is to be able to speak and interact with people from other countries; however, a student said that it would be very difficult to speak in English because they had to learn a great deal of vocabulary.

\section{Segment 1}

Teacher: Arianna, ¿Crees que las actividades de inglés que desarrollas en el colegio te permitirán hablar con un extranjero?

Arianna: No, profe porque yo casi no entiendo, pero si me aprendo las palabras de pronto.

On the other hand, they found the class participation important to learn English, but they do not often take part in them actively to avoid being ridiculed by their peers and on-the-spot corrections of the teacher before their classmates. Next, they were inquired if they would participate more if their classmates did not mock them or the teacher did not correct them on the spot; they said that even if their classmates did not say anything, they often felt embarrassed of speaking in front of the class.

\section{Segment 2}

Camilo: Me daba miedo que se me fuera a olvidar.

Teacher: ¿O sea que te lo aprendiste de memoria?

Camilo:Sí, yo me lo aprendí.

These students also expressed that they were insecure to improvise dialogues in front of their classmates. Due to this, they preferred writing down the questions, their answers and memorize them. One of the main reasons of this insecurity had to do with the fear to make 
mistakes when pronouncing in English and the constant correction made by the teacher.

\section{Segment 3}

Camilo: Yo no sé hablá' inglés profe, por eso me da pena delante de los demás porque no sé decir bien las palabras y me aturdo cuando la profe me dice que repita.

Teacher: ¿Cómo así que te aturdes?

Camilo: iQué no me sale la pronunciación!

Finally, the students were questioned about their reactions when they had to perform before their classmates. They mentioned some anxiety symptoms such as laughter, trembling voice and watery eyes. They experienced these reactions, especially, in oral dialogues without reading.

Keeping the objective of this interview in mind, it is worth mentioning that the students felt comfortable at talking about their feelings and attitudes toward the class participation. Through their answers, it was noticed that they wanted to learn English, but the class participation was difficult due to some factors such as nervousness, anxiety, mockery from their partners, the teachers' corrections and the mispronunciation.

\section{Description of the questionnaires conducted to the target group and the teacher}

\section{Students' questionnaire}

The questionnaire was administered to 37 students of $8^{\text {th }} \mathrm{A}$ grade at San Jose de Luruaco School and consisted of nine questions. Most of them were closed; nevertheless, it was necessary to ask for a justification based on their choices to garner comprehensive information for this study.

The first question: ¿Te sientes motivado a participar en las actividades de la clase de inglés? This question shed light on the students' motivation to participate in class. Most of them manifested they felt motivated to participate in the activities to learn more English and to have fun. The rest of the students uttered they did not do it because their English level was too low or they disliked the subject matter.

The second question: Cuando el profesor propone actividades de participación oral ¿participas por gusto, por obligación, por la nota o prefieres no participar? This question attempted to know the main reasons for the target group to partake in oral activities. 10 of them argued that they got involved because they liked these types of activities; 20 students contended they did it just for the grade or for the pressure made by the teacher; two students alleged they preferred not participating in them.

Third question: ¿Cómo te sientes cuando debes emplear el idioma inglés para una actividad oral o para comunicarte con tus compañeros y profesor? The students were given five options to choose: a. Tranquilo; b. Animado; c. Tensionado; d. Inseguro; e. Avergonzado. This question elicited about their feelings or attitude towards oral activities or using English for communicating with the teacher and their classmates in class. 15 students expressed they felt driven to do it 
when prepared for an oral presentation or because they wanted to learn more about how to pronounce words and to have passing grades. Other students said they felt insecure, stressed or embarrassed because they thought they would be given a non-passing grade or they were scared of making mistakes, especially, in pronunciation, or they considered they could forget what they had to say because of their nervousness.

Fourth question: ¿Crees que es importante emplear el inglés como medio de comunicación oral en la clase? This question was chiefly aimed at finding out how important the students considered the use of English for communicating freely in class and not only for performing an oral presentation such as memorized dialogues or role-plays previously prepared. Most of them agreed that communicating in English is important to improve their communication skills in this language and to enrich the knowledge of the language as well.

Fifth question: ¿Cuándo tienes que hacer una presentación oral en inglés, te preocupas por las reacciones de tus compañeros? This question inquired about the concern of speaking English in front of the whole class. 27 students said they worried about the comments of their peers when they had to perform orally in English mainly because they felt embarrassed of being ridiculed by their classmates. Sometimes they did not respect the participation of their classmates; even they made jokes that inhibited some of them to participate actively.

Based on the information given by the students in the aforementioned questions, most of them are not actually motivated to use the language for communication. They resort to the foreign language merely to have a passing grade. In fact, the target group does not view the target language as an instrument for communicating in the classroom or outside of it, although they were aware of the importance of using the language to practice more and improve their knowledge. The main concerns of these students were to communicate and participate in class using the foreign language for fear of making mistakes in pronunciation and the mockery coming from their partners. These are some of the factors that affect the free or controlled oral production in class.

As far as the activities developed in English classes are concerned, the ensuing questions looked into the oral activities implemented in class.

Question six: ¿Consideras que las actividades orales propuestas en la clase te motivan a participar voluntariamente? This question had three options to choose: Si, no y algunas veces. 20 students said algunas veces. At this point, the students reiterated that they sometimes did not participate voluntarily because they did not feel confident enough to perform neither in front of their partners nor the teacher. Despite this, they regarded some of the activities as fun and they liked getting involved in them. Their participation depended mostly on the activity proposed.

In the question 7: ¿Por qué crees que todos los compañeros no participan en las actividades orales? This question referred to the lack of participation involving oral activities. With regard to this, the students expressed some of the reasons of their nervousness to participate in oral activities such as shame, lack of study and shyness.

Question 8: ¿Qué actividades orales no te agradan?This inquired about the type of activities 
they disliked to perform in class. The students listed the role-plays as well as the oral presentations, especially, when they had to previously study something and say it to the whole class.

Question 9: ¿Qué actividades te gustaría que se implementaran en la clase de inglés? This revolved around the target group's preference over the activities carried out in class. They mentioned activities like games, Power Point presentations (PPT), word search puzzles and others they considered appealing and interesting.

As seen above, the overall responses of the last 5 questions show clearly that the target group is conscious of the importance of the English language for communication purposes. In addition, they prefer carrying out some other motivating activities to develop this skill in class. One of the major concerns had to do with the negative reaction their peers had when performing before them. This brings about nervousness and unconformity hampering communication.

\section{Teacher's questionnaire}

After having described the data obtained from the questionnaire applied to the target group, it is necessary to know the teacher's considerations about the feelings and attitudes towards the students and the class activities, in particular, the oral participation. The applied questionnaire comprised of eight open questions. The teacher was given the questions to answer them, and then she was asked to justify each response during a dialogue with the interviewer.

First question: ¿Qué habilidades son más desarrolladas en el aula: escritas u orales? The teacher stated that the most developed ability in class was writing because it was easier to keep the students busy by having them work on written worksheets and transcripts from the board. Contrary to this, speaking and listening were more challenging to develop because of the number of students.

The second question was aimed to know about the motivation demonstrated by the students during the development of the communication skills: ¿Los estudiantes se muestran más motivados en actividades de listening, reading, writingo speaking? According to the teacher's perception, the students are more motivated when participating in reading and writing activities. Most of the activities proposed in class are addressed to develop these skills; consequently, the students were not acquainted with speaking activities, and they might think that these were not very important for their language learning.

In order to know more aboutthe use of theforeignlanguage in class, thethirdquestionwas: ¿Cuándo tus estudiantes deben emplear el idioma Inglés para una actividad oral o para comunicarse con sus compañeros y profesor, tú consideras que la mayoría de ellos se sienten tranquilos, animados, tensionados, inseguros $u$ otro? Despite the lack of speaking activities performed in class, the teacher replied that most of the students felt motivated when using the foreign language to communicate with the other classmates and the teacher. Some of them were insecure when they did not manage the topic very well, and they became ashamed before their classmates. 
Question number four focused on finding out the teacher's opinion about the importance of giving the class mainly in English: ¿Qué opina de enseñar la mayor parte de la clase en inglés? To this regard, she agreed that prior to doing that, it was necessary to give the students an authentic learning environment where they could realize that learning a foreign language is fun.

The fifth question was about the kind of activities that the teacher proposes to encourage participation in oral activities: ¿Qué tipo de actividades propones para incentivar la participación en actividades orales? The teacher answered that she always planned oral activities such as conversations, dialogues in pairs, games, videos and songs. Despite the fact that these activities seemed to be very motivating, there were some students reluctant to participate in them.

The sixth question asked about the reasons for the students to be reluctant to participate in oral activities: ¿Por qué crees que algunos estudiantes no participant en las actividades orales? The teacher stressed that she observed that some students disturbed their peers when they tried to express their ideas in English; it could be one of the main causes of their reluctance to use the language for communication purposes in class. Consequently, the teacher needed to make a big effort to motivate this group of students.

The next question elicited about the motivation to speak in English in class and the factors that may affect the voluntary participation: ¿Consideras que la clase de inglés motiva a los estudiantes a hablar en este idioma?, o por el contrario existen algunos factores afectivos 0 cognitivos que impiden su participación voluntaria? En este caso, silos has notado, ¿Cuáles son? The teacher pointed out that the motivation for participating in class had improved. Now they were more willing to do it; for instance, they viewed mistakes as something normal for learning; however, there were some factors that may have inhibited the student's participation such as fear, lack of commitment or interest, teasing and disrespect.

The last question focused on the most difficult oral activities for the target group: ¿Qué actividades orales consideras que son de mayor dificultad para los estudiantes? She replied that the spelling and the listening activities were much more difficult for their students. These were some of the factors that contributed to hamper communication among the students.

The responses listed above show that the listening and spelling activities are not easy for the target group and the teacher should provide enough practice of this type of activities to make students feel more confident and secure on the development of these abilities. In doing so, they might overcome their difficulties and try to produce more in terms of speaking.

\section{Discussions y conclusions}

Once the data were screened, the following findings emerged regarding the research question: How do affective factors affect the oral participation of the students in activities proposed by the teacher? These factors were classified as anxiety, low motivation for communication, low self-confidence in learning a foreign language, teacher's method to monitor oral activities, fear of making mistakes and being ridiculed by peers. Each one of them is developed below. 


\section{Anxiety}

The analysis of the data demonstrated the high level of anxiety caused in the students when participating in oral activities. This was evident when they were reluctant to speak in the English class because of their nervousness and tension, which hampered effective communication. In addition, they felt anxious when it came to speaking English mainly due to the fear of making mistakes or being mocked affecting their self- esteem.

During the classroom observations, the students showed some symptoms of anxiety such as trembling voice, watery eyes, and laughter without reason. They also mentioned others in the interview such as palpitation, stomachache and mental block. Some of the students pointed out that they could cope with anxiety and reduce it provided that they had prepared the activity beforehand, but other students expressed that even when they had already rehearsed the activity, they were not able to control it, and they felt inhibited to participate voluntarily and preferred waiting for their turn to speak. Some studies (Aghajani \& Amanzadeh, 2017; Rajitha \& Alamelu, 2020; Ronauli \& Irzawati, 2019) have also arrived at the same conclusion as this one relating anxiety with affective factors.

\section{Low motivation for communication}

Communication should be the ultimate goal for most of the activities in the English class and through the participation in oral activities, students will improve their ability to communicate with others; nevertheless, after revising the information taken from the instruments, it is evident that there is a low motivation in communication using the target language. These students felt obliged to practice English in oral activities. Actually, they just wanted to have passing grades.

In the questionnaire given to the whole group, most of the students manifested that they were motivated to take part in the oral activities because these were appealing, and they wanted to learn more from them. The former contrasted with the classroom observations, where the teacher encouraged the target group to carry out these activities without being scored with the aim of lowering the affective filter and fostering class participation.

On the other hand, the students argued that having a passing grade was a strong motivation to perform well in oral activities such as dialogues or role-plays. Due to this, they always made an effort to do well in class. Others were really concerned about the grade and considered speaking a very demanding skill. According to them, performing in front of the class was the worst experience. In order to avoid this, they preferred other types of activities to be evaluated such as completing grammar exercises or writing activities.

Based on the data arising from the instruments, instrumental motivation seems to be the most common one in the classroom. English teachers must encourage or motivate their students to improve their speaking skill. The majority of these students do not learn English for pleasure, butjust for obligation. In that sense, teachers "instead of appearing to a judge or someone who is putting them under pressure whilst testing and giving them a grade, the teacher more in the role of a drama coach, encouraging and simulating the idea that they are real actors working in the studio with a director who is there to help them get it perfect" (Dubey, 2019, p.69). 


\section{Low self-confidence in learning a foreign language}

In the classroom observations, it emerged that the students needed to improve their English level. They required learning more vocabulary and practice speaking to improve their pronunciation. According to their responses arising from the questionnaire, they were conscious of the necessity to practice English in the classroom to enhance communicative skills; nevertheless, they were not willing to participate in class because they were insecure about their knowledge, especially, pronunciation. Likewise, the majority of them stressed that the pronunciation of words in English is difficult, in particular, when they have to perform in front of their classmates. This situation might be related to low self-confidence.

In the context of this study, the target group neither dropped out of the class nor took part voluntarily in the oral activities. During the open interview, one of the students uttered that she would like to communicate with people from other countries in English, but she considered that the oral activities developed in the class were not useful to speak English naturally because English is very difficult and the pronunciation is really troublesome. This student also added some of her classmates pronounced or answered in a low voice because they were not sure about what they could do with the target language. These students did not trust in their language learning; they felt compelled to participate and learn basic elements to obtain passing grades for the English course. A couple of research studies are in agreement with the results obtained based on the negative effects of low self-confidence when learning a foreign language (Gürler, 2015; Nadiah, Arina \& Ikhrom, 2019; Tridinanti, 2018).

\section{Teacher's method to monitor oral activities}

The teacher's role in the classroom is of great relevance for students to achieve the goals of language learning. After planning the activities to encourage students to participate and promote effective communication in the classroom, the teacher should monitor the development of the activities and foster an appropriate environment where students could be comfortable to use the target language and participate in oral activities.

The results emerged from the questionnaire showed that the target group was satisfied with the teacher. As a matter of fact, some of them remarked that they liked the teacher's methodology because she encouraged them to learn the language. Although the classes were focused on vocabulary and grammar, the teacher also included some activities to develop speaking and make students use the language in a meaningful way. This view is shared by teachers who are their students' facilitators, assistants and guides. They provide assistance and support through scaffolding to build up interaction in all English learning activities in class, especially to promote oral participation (Rahmawati, 2015).

\section{Fear of making mistakes and being ridiculed by their peers.}

Regarding the information gathered from the students, one of the main causes of reluctance to participate in oral activities is the fear of making mistakes and being ridiculed by their classmates. 
In the questionnaire, the target group highlighted that they were really worried not only about the teacher's evaluation, but also about their partners' opinion when they spoke English. Most of them expressed that they did not like participating in oral activities before the whole class because some classmates did not respect when a student was performing an oral activity. Obviously, the teacher tried to control that, but sometimes it was ineffective. In the classroom observations, the former view was reiterated when the teacher had to call on the students to participate in the activities regardless of their classmates' mockery. As a result of this situation, the students did not take the risk themselves of speaking in class, and risk taking is one of the important characteristics of successful learning in a second or foreign language. "It is the communication and interaction between a teacher and students in which teachers give instructions to support the understanding in the language class" (Rahmawati, 2015, p.2).

Below you can find some of the pedagogical implications that can foster effective oral activities in class to overcome some constraints presented in this study. Both teachers and students can benefit from them thoroughly:

- Teachers should be conscious of the abilities, needs and fears of each student in class, which might contribute to the search of strategies that allow students to become more active to speak English in oral activities individually, in pairs or in small groups. This way, students can gain confidence making them participate in the activities and exercise proposed and suggested without being forced to do them.

- Teachers ought to carry out more pair activities in class to lower the levels of anxiety in students and make them gain confidence. Thus, they can perform any activity even before their classmates.

- Oral activities should be adjusted to students' interest. The use of a wide range of activities such as games, conversations in small groups, meaningful topics could be considered by the teacher in order to develop the students' communicative skills.

- Activities to learn new vocabulary and exercise pronunciation should be proposed and favored by teachers prior to the oral communicative activities; this preliminary practice could help students feel more confident about using new words and grammar to communicate and participate orally.

- Promotion of cooperation and collaborative learning among students could aid in creating a harmonic environment, in which students feel free to speak and be capable to accept comments as well as suggestions from teachers and classmates as opportunities to improve their communicative competence.

- Teachers should focus on students' strengths rather than their weaknesses. This could be a way of reducing their inhibition to speak and improve their levels of self-esteem.

- The correction of mistakes should take place in a friendly and cooperative atmosphere, in which students learn from their mistakes without feeling threatened or teased by others.

- Teachers could train students in using speaking strategies to overcome their difficulties.

Considering that communication should be the aim of all language teaching process, the current interest for expanding knowledge through the immersion in different cultures and the 
necessity to have better career opportunities in the globalized world has shed light on the varied factors that inhibit students to develop their communicative competence in the classroom.

In order to respond to the research question: what are the factors that cause the reluctance of students to participate in oral activities in eighth grade students at San Jose de Luruaco School?, it was essential to understand the behavior of students towards oral activities and analyze both the teacher and the students' role during these activities. For this, the qualitative research selected provided the most suitable methods and tools to have a broader understanding of the factors affecting what actually happens in class through the analysis of the different perspectives of the participants involved.

One of the factors affecting reluctance of participation is anxiety which is regarded as a typical reaction of the target group when they have to perform orally in the English class. The teacher encouraged her students to use the target language in class, but some of the activities proposed were not suitable for attaining this objective. During the analysis of the interviews and the classes observed, it was evident that most of the classes were focused on grammar and writing activities. The target group considered English as a subject, where vocabulary and grammar structures have to be learned mechanically to have passing grades.

On the other hand, the permanent translation into Spanish lead students to feel free to use only Spanish for communicating in class and understanding what the teacher says without making any effort to grasp the information or instructions in English. Therefore, it is useless to ask students to speak English in class if the teacher does not use the target language most of the time whereas the Spanish language is still the main means of communication to have a better understanding of the lessons and the instructions of the activities. As a result, the group was not accustomed to practicing speaking, and they were reluctant to speak English and take part in oral performances.

Another important finding that emerged from the data was that anxiety seems to be the predominant factor that affects the students' participation in oral activities and the low development of communicative skills in the classroom. It can also be concluded that the principal causes of foreign language anxiety were embedded in other factors such as lack of confidence, lack of good pronunciation and limited vocabulary. The aforementioned reasons can increase the levels of anxiety and inhibit them to participate actively in the proposed activities.

Another salient point to bear in mind is that of motivation. The students were highly motivated to partake in class mainly to have a passing grade. On the other hand, the improvement of communicative skills is not relevant for students; one of their major concerns at the time of participating was the fear of negative evaluation.

As mentioned before, the teacher's attitude towards the mistake correction also influenced the reluctance of participating in oral activities; the teacher's on-the-spot corrections at the moment of speaking interrupted the natural flow of the dialogue and increased the students' anxiety who preferred to remain quiet instead of speaking and being corrected before the group.

Similarly, the fear of being criticized or ridiculed in front of their classmates was another factor that inhibited students' oral performance in class. Apart from anxiety, the lack of having 
a good command of English, the fear of having a non-passing grade and the reaction of their partners when they committed errors, it was usually cause of embarrassment and a strong motive to be reluctant to participate voluntarily in oral activities.

The identification of these factors was really relevant and significant because sometimes the real causes of the situations considering the low participation of some students in class are ignored. Even though teachers encourage students to speak in the target language as a way for improving their speaking abilities, the effect could be the opposite if the internal and external factors that affect the use of English to get involved in class are not considered.

Hence, it is necessary that teachers consider the variety of personalities that their students have in the classroom when planning their lessons to present suitable speaking strategies that may encourage all students to participate in oral activities. In addition, promoting different types of activities that favor cooperation and collaborative learning among students might help create an appropriate environment for students to take the risk to talk to others and receive feedback from them to improve their knowledge of the language without being intimidated from their peers.

Finally, these results indicate that students recognized the importance of communicating in the target language and demonstrate interest in learning the language with speaking purposes. As a matter of fact, they acknowledged they had some limitations such as lack of vocabulary and good pronunciations, which hampered communication because they were afraid of negative evaluation or being mocked before their classmates. It is worth stressing that further research study of the issue is still required to deepen into the factors that affect the development of speaking activities in class and design activities that respond to students' communication needs and also encourage teachers to see beyond the evaluation of students' performance and provide permanent motivation for class participation and language use as a means of effective communication in class.

\section{References}

Aghajani, M., \& Amanzadeh, H. (2017). The effect of anxiety on speaking ability: an experimental study on efl learners. Journal of Applied Linguistics and Language Research, 4(7), 154-164.

Ahmadi Safa, M. \& Rozati, F. (2017). The impact of scaffolding and nonscaffolding strategies on the EFL learners' listening comprehension development, The Journal of Educational Research, 110(5), 447-456. https://doi.org/10.1080/00220671.2015.1118004

Ariyanti, M. (2016). Psychological Factors Affecting EFL Students' Speaking Performance. ASIAN TEFL1(1), 91-102. http://dx.doi.org/10.21462/asiantefl.v1i1.14

British Council. (n.d.). Speaking. https://learnenglish.britishcouncil.org/skills/speaking 
Campbell, R., \& Wales, R. (1970). The Study of Language Acquisition. In Lyons, J. (Ed.), New Horizons in Linguistics (pp. 242-260). Harmondsworth: Pinguin Books Ltd.

Canale, M., \& Swain, M. (1980). Theoretical Bases of Communicative Approaches to Second Language Teaching and Testing. Applied Linguistics, (1), 1-47. https://doi.org/10.1093/applin/I.1.1

Colin, J. \& Shamus, K. (Eds.). (2018). Approaches to ethnography: analysis and representation in participant observation. Oxford University Press. https://doi.org/10.1177/1468794118808203

Cotter, Ch. (2007). Speaking well-four steps to improve your ESL EFL students speaking ability. https://rb.gy/izwvgm

Council of Europe. (2018). Common European Framework of Reference for Languages: learning, teaching, assessment. Companion volume with new descriptors. http://rm.coe.int/cefrcompanion-volume-with-new-descriptors-2018/1680787989

Dubey V. (2019). Enhancing speaking skills. Evincepub publishing.

Duell, N. \& Steinberg, L. (2018). Positive risk taking in adolescence. Child Dev Perspect, 13(1), 48-52. https://doi.org/10.1111/cdep. 12310

Elaldi, S. (2016). Foreign language anxiety of students studying English language and Literature: a sample from Turkey. Educational Research and Reviews, 11(6) 219-228. https://doi.org/10.5897/ERR2015.2507

Galajda, D. (2017). Communicative behaviour of a language Learner: exploring willingness to communicate. Springer. https://doi.org/10.1007/978-3-319-59333-3

Gómez Sará, M. M. (2017). Review and analysis of the Colombian foreign language bilingualism policies and plans. HOW, 24(1), 139-156. https://doi.org/10.19183/how.24.1.343

Gürler, I. (2015). Correlation between Self-confidence and Speaking Skill of English Language Teaching and English Language and Literature Preparatory Students. Curr Res SocSci, 1(2), 14-19.

Hamouda, A. (2013). An exploration of causes of Saudi students' reluctance to Participate in the English language classroom. International Journal of English Language Education, 1(1), 17-34. https://doi.org/10.5296/ijele.v1i1.2652

Hameed Panhwar, A., Ansari, S. \& Ansari, K. (2016). Sociocultural theory and its role in the development of language pedagogy. Advances in language and literary studies. 7(6), 183-188. https://doi.org/10.7575/aiac.alls.v.7n.6p.183

Heckhausen J., Heckhausen H. (2018). Motivation and action: introduction and overview. In: Heckhausen J., Heckhausen H. (Eds.) Motivation and action (3er ed., pp. 1-14). Springer, Cham. https://doi.org/10.1007/978-3-319-65094-4_1 
Heini-Marja P. (2019). Teaching speaking. Apples-Journal of Applied Language Studies. 13(1), 95-111. http://dx.doi.org/10.17011/apples/urn.201903011691

Hoang Tuan, N. \& Ngoc Mai, T. (2015). Factors affecting students' speaking performance at le Thanh Hien high school. Asian Journal of Educational Research, 3(2), 8-23. http://www.elfadel.net/pdf-view?scientificMessages=20

Hughes, R. \& Szczepek Reed, B. (2017). Teaching and Researching Speaking (3er ed.). Londres: Routledge.

Humaera, I. (2015). Inhibition in speaking performance. Journal of The Association for Arabic and English1 (1), 31-50. https://dx.doi.org/10.31332/lkw.v1i1.379

Hymes, D. (1966). Two types of linguistic relativity. In W. Bright (Ed.), Sociolinguistics. (pp.114-158). Uk: The Hague Mouton.

Hymes, D. (1972). On Communicative Competence. In J.B. Pride \& J. Holmes (Eds.). Sociolinguistics. (pp. 269-293). Uk: Penguin Books.

Karahan, F. (2007). Language attitudes of Turkish students towards the English language and its use in Turkish context. Journal of Arts and Sciences, (7), 73-87.

Kivunja, C. \& Kuyini, A. (2017). Understanding and applying research paradigms in educational contexts. International Journal of Higher Education, 6(5) 26-41. https://dx.doi.org/10.5430/ijhe.v6n5p26

Koran S. (2015). The Role of Teachers in Developing Learners' Speaking Skill. 6th International Visible Conference on Educational Studies and Applied Linguistics. https://www.researchgate.net/publication/322112785_The_Role_of_Teachers_in_Deve loping_Learners'_Speaking_Skill

Lai-Mei, L \& Seyedeh, M. A. (2017). An analysis of factors influencing learners' english speaking skill. International Journal of Research in English Education, 2(1), 34-41. https://dx.doi.org/10.18869/acadpub.ijree.2.1.34

Lantolf, J. \& Thorne, S. (2007). Sociocultural Theory and Second Language Learning. In. B. Patten \& J. Williams (Eds.), Theories in Second Language Acquisition (pp. 201-224). Estados Unidos: Lawrence Erlbaum.

Marín, I. (2013).The Role of Risk-Taking Behavior in the Development of Speaking Skills in ESL Classrooms.Revista de LenguasModernas, 421-435. https://pdfs.semanticscholar.org/96cf/7b5ceeece802825f486b80c32e25c214908d.pdf

McDonough, K. \& Mackey, A. (2013). Second Language Interaction in Diverse Educational Contexts. John Benjamins Publishing Company. https://doi.org/10.1075/IIt.34

Ministerio de Educación Nacional. (2014). Programa Colombia Bilingüe 2014-2018. http://www.colombiaaprende.edu.co/html/micrositios/1752/w3-article-315515.html 
Ministerio de Educación Nacional. (s.f.). Programa Nacional de Bilingüismo 2004-2019. https://rb.gy/feq7yohttps://doi.org/10.19052/978-958-8844-60-2

Ministerio de Educación Nacional. (s.f.). Programa Nacional de inglés "Verywell" 2015-2025. https://rb.gy/2roj1b

Ministerio de Educación Nacional. (s.f.). Proyecto de Fortalecimiento al Desarrollo de las Competencias en Lenguas Extranjeras PFDCLE 2010-2014. https://rb.gy/os1qo7

Nadiah, Arina \& Ikhrom. (2019). The Students' Self-Confidence in Public Speaking. ELITE Journal, 1(1), 1-11. https://doi.org/10.30605/jsgp.2.1.2019.1263

Nie, Y. (2018). Affective Factors Influencing Oral English Teaching. 3rd International Seminar on Social Science Humanistic Education. https://doi.org/10.12783/dtssehs/sshe2018/26441

Nunan, D. (2015). Teaching English to Speakers of Other Languages: an introduction. Londres: Routledge.

Nunan, D. (2018). Teaching Speaking to Young Learners. The TESOL Encyclopedia of English Language Teaching, (2018), 1-8. https://doi.org/10.1002/9781118784235.eelt0715

Oga-Baldwin, W.L.Q., Fryer, L.K. (2018). Schools can improve motivational quality: profile transitions across early foreign language learning experiences. MotivEmot, (42), 527545. https://doi.org/10.1007/s11031-018-9681-7

Rahmawati, T. (2015). The use of scaffolding talk technique to improve students' speaking skill (Classroom Action Research of the Eighth Grade Students of MTs NegeriAndong in the Academic Year of 2013/2014). [Doctoral thesis, STAIN, Salatiga]. https://rb.gy/53ndgv

Rajitha, K., \& Alamelu, C. (2020). A study of factors affecting and causing speaking anxiety. Procedia Computer Science,

(172), 1053-1058. https://doi.org/10.1016/j.procs.2020.05.154

Richards, J. (2006). What is communicative language teaching today? In D.J. Communicative language teaching. (pp. 2-5). Uk: Cambridge University Press.

Richards, K. (2003). Qualitative Research in TESOL. PalgraveMacmillan. https://doi.org/10.1057/9780230505056

Robertson, P. (2018). Oral corrective feedback on students' grammatical accuracy and willingness to communicate in efl classroom: the effects of focused and unfocused prompts. Asian EFL Journal, 20(4), 232-253. https://www.asian-efl-journal.com/wpcontent/uploads/AEFLJ-Volume-20-Issue-4-April-2018. pdf\#page $=232$

Rohmah, I. (2017). Classroom interaction in English language class for students of economics education. Arab World English Journal, 8(2), 192-207. https://dx.doi.org/10.24093/awej/vol8no2.14 
Ronauli, A., \& Irzawati, I. (2019). Students' speaking anxiety on their speaking performance: a study of efl learners. Advances in Social Science, Education and Humanities Research, (394), 101-106.

Savignon, S. (1972). Communicative competence: an experiment in foreign language teaching. Uk: The Centre for Curriculum Development, Inc.

Swain, M., Kinnear, P. \& Steinman, L. (2015). Sociocultural theory in second language Education: an introduction through narratives. Second edition. https://doi.org/10.21832/9781783093182

Tridinanti, G. (2018). The correlation between speaking anxiety, self-confidence, and speaking achievement of Undergraduate EFL students of private university in Palembang. International Journal of Education \& Literacy Studies, 6(4), 35-39. https://doi.org/10.7575/aiac.ijels.v.6n.4p.35

Vygotsky, L. (1986). Thought and language. Estados Unidos: The MIT Press. 